\title{
Simon Karlinsky, 1924-2009
}

Simon Karlinsky was in his eighty-fifth year when he died at his home in Kensington, California, on 5 July 2009 . He was surrounded in his later years by friends and colleagues, two devoted caregivers and his beloved companion of thirty-five years, Peter Carleton (whom he was able to marry only in 2008).

A prolific, provocative, and controversial scholar of modern Russian literature, Karlinsky taught at the University of California, Berkeley, for some thirty years. His path to academic life was anything but direct, and it was not at all clear that he was destined for a scholarly career. An only child, he was born on 22 September 1924 in the Russian enclave of the Manchurian city of Harbin. Here he received his primary education and developed his tastes for music and literature. The family left for the United States in 1938. Karlinsky attended high school and college in Los Angeles before enlisting in the U.S. Army in 1944. Between 1945 and 1951 he served as a Russian interpreter in occupied Berlin, not only for the Army but, after discharge from the Army, for the American military government and the office of the High Commissioner for Germany. He spent a year (1951-1952) in Paris, where he studied musical composition under Arthur Honegger at the École Normale de Musique. Subsequently he returned to Berlin, where from 1952 to 1957 he was employed again as liaison officer and interpreter for the U.S. Berlin Command. During that period he continued his studies under Boris Blacher at the Staatliche Hochschule für Musik, and several of his scores were performed and published.

Karlinsky remained deeply involved in music and dance throughout his life, and the music of Igor' Stravinskii was the object of his particular admiration. His early love of literature (Russian, French, English, and, in time, German and Polish) came to the fore, however. He received a BA from the University of California, Berkeley, in 1960, an MA from Harvard University in 1961, and a PhD in Slavic Languages and Literatures from Berkeley in 1964 - where he was immediately appointed to the faculty and rose rapidly to become a full professor in 1967. Karlinsky taught with great panache a wide variety of courses and seminars, including advanced language and stylistics, surveys of eighteenthand nineteenth-century Russian literature, Russian Romanticism, Russian modernism, the history of the Russian theater and drama, as well as single-author courses on Aleksandr Pushkin, Nikolai Gogol', Lev Tolstoi, and Anton Chekhov. He retired in 1991.

Karlinsky was twice awarded the Guggenheim Fellowship, and his career as a publishing scholar was extraordinary. His first, pioneering book (his revised dissertation, written under the direction of G. P. Struve) was on Marina Tsvetaeva and appeared in 1966. This study was the result of Karlinsky's resourceful research into her biography and his inspired close reading of her wildly idiosyncratic poetry. His work became the cornerstone for future Tsvetaeva studies, well before her renown either in the west or in Soviet Russia. His second book on her, published in 1985, took full advantage of the mass of research and analysis inspired by his initial study.

To be reckoned among Karlinsky's most valuable contributions, widely read inside and outside the profession, is his now-standard edition of the selected letters of Chekhov (1973). He collaborated closely on the translations by Michael Henry Heim, and his erudite, scintillating introduction and annotations to the letters comprise a virtual critical biography of the writer whom he considered an exemplary human being

Other volumes under Karlinsky's editorship were signposts in the English-language reception of Russian émigré literature, a phenomenon that he knew firsthand. He was responsible for a two-volume issue of the journal TriQuarterly in 1974 that was devoted to Russian literature and culture in the west (this was republished in 1977 as The Bitter Air of Exile: Russian Writers in the West, 1922-1972). His contributions therein included introductions, articles, commentary, and translations. For Karlinsky, Vladimir Nabokov was a preeminent figure (long before his fame as an English novelist), and he wrote frequently and discerningly about him. Karlinsky's edition of the Russian writer's correspondence 
with the American critic Edmund Wilson, The Nabokov-Wilson Letters, 1940-1971 (1979; German expanded edition, 1995; revised and expanded, Dear Bunny, Dear Volodya, 2001) was widely hailed.

Meanwhile, The Sexual Labyrinth of Nikolai Gogol had been published in 1976 and provoked a storm of controversy over its assertion of the reflection in the writer's life and work of repressed homosexual tendencies. This study signaled a series of articles, reviews, translations, and conference appearances on sexual politics, homosexual themes, and queer theory that were at the time almost unprecedented in the study of Russian literature and culture. Karlinsky's writings on the subject appeared primarily in the leading gay outlets, but his concerns were raised across the board. Questions that he addressed included the virulently homophobic nature of Marxist-Leninist ideology in practice, repression and persecution in Soviet Russia, and the hidden and not-so-hidden lives of some Russian figures of prominence.

The author himself considered his Russian Drama from Its Beginnings to the Age of Pushkin (1985), a book that grew out of an admired course in the history of the Russian theater, his greatest achievement. It is the result of monumental research and thinking about the origins and early development of the earlier Russian theater. His colleagues still lament the fact that he never produced a follow-up, for he was a rare connoisseur of the plays of Gogol', Aleksandr Ostrovskii, Tolstoi, Chekhov, and the Russian symbolist theater.

A steady stream of articles and reviews in such mainstream media as the New York Times Book Review, TLS, and the Nation, as well as in professional journals, dealt with a wide gamut of subjects and personalities. Karlinsky ranged from saints' lives and the Domostroi to Soviet institutions; from eighteenth-century Russian comic opera to Petr II'ch Chaikovskii, Maurice Ravel, Sergei Diagilev, Stravinskii, and Dmitrii Shostakovich; from the prose of Gogol', Fedor Dostoevskii, Tolstoi, and his revered Chekhov to the novels of Nabokov and Aleksandr Solzhenitsyn. He devoted special attention to modernist poetry and drama (Zinaida Gippius, Innokentii Annenskii, Mikhail Kuzmin, acmeists, futurists, and Soviet-era poets) and was the enthusiastic champion of such younger émigré poets as Valerii Pereleshin and Nikolai Morshen.

Karlinsky commanded a nuanced knowledge of both Russian and English. He was a master of simultaneous translation, a superb interpreter-and performer-of literary texts. Numerous translations of works by and about Russian writers bear his imprint, both acknowledged and silent; his readings of many major texts will endure.

Annotated lists of his publications appear in the Festschrift in his honor, For SK. In Celebration of the Life and Career of Simon Karlinsky (1994; ed. M. Flier and R. Hughes; bibliography compiled by Molly Molloy) and, accompanying an entry by C. Putney, in the Gay and Lesbian Literature Encyclopedia (1998), vol. 2.

\author{
ROBERT P. HugheS \\ University of California, Berkeley \\ May 2010
}

\title{
Richard Stites, 1931-2010
}

Russian history has lost one of its most visionary pioneers and inspirational mentors. After a short struggle with cancer, Richard Stites died on 7 March 2010 in Helsinki, his much loved summer residence and research base. Born in Philadelphia on 2 December 1931 and raised in a mostly blue-collar neighborhood, Richard attended Catholic and public schools before obtaining his BA at the University of Pennsylvania in 1956. Three years later, he received an MA in European history from George Washington University and, in 1961, enrolled in the PhD program at Harvard, where he was taught by Nicholas Riasanovsky, wrote his dissertation on the women's question under the mentorship of Richard Pipes, and received his doctoral degree in 1968 . He was awarded an honorary doctorate from the University of Helsinki in 2003. Richard's teaching career began in 1959 at Lycoming College and subsequently included the International College in Copenhagen, Brown University, and the Ohio State University (Lima Campus). From 1977 until his death, he 